Western North American Naturalist 69(4), (C) 2009, pp. 556-562

\title{
CONTROLS ON RADIAL GROWTH OF MOUNTAIN BIG SAGEBRUSH AND IMPLICATIONS FOR CLIMATE CHANGE
}

\author{
Rebecca E. Poore ${ }^{1,2}$, Christine A. Lamanna ${ }^{3,4}$, James J. Ebersole ${ }^{1}$, and Brian J. Enquist ${ }^{3}$
}

\begin{abstract}
Mountain big sagebrush (Artemisia tridentata Nutt. ssp. vaseyana) covers large areas in arid regions of western North America. Climate-change models predict a decrease in the range of sagebrush, but few studies have examined details of predicted changes on sagebrush growth and the potential impacts of these changes on the community. We analyzed effects of temperature, precipitation, and snow depth on sagebrush annual ring width for 1969 to 2007 in the Gunnison Basin of Colorado. Temperature at all times of year except winter had negative correlations with ring widths; summer temperature had the strongest negative relationship. Ring widths correlated positively with precipitation in various seasons except summer; winter precipitation had the strongest relationship with growth. Maximum snow depth also correlated positively and strongly with ring width. Multiple regressions showed that summer temperature and either winter precipitation or maximum snow depth, which recharges deeper soil horizons, are both important in controlling growth. Overall, water stress and perhaps especially maximum snow depth appear to limit growth of this species. With predicted increases in temperature and probable reduced snow depth, sagebrush growth rates are likely to decrease. If so, sagebrush populations and cover may decline, which may have substantial effects on community composition and carbon balance.
\end{abstract}

Key words: Artemisia tridentata, sagebrush, dendrochronology, Gunnison Basin.

Mountain big sagebrush (Artemisia tridentata Nutt. ssp. vaseyana) a dominates upland sites in the $540,000-\mathrm{km}^{2}$ area in the Intermountain West occupied by big sagebrush (Artemisia tridentata) (McArthur and Ott 1996). Mountain big sagebrush grows at the upper elevational range of big sagebrush and generally establishes in cooler, moister sites from about 2000 to $2800 \mathrm{~m}$ (West et al. 1978, Shultz 2006).

As the community dominant (McArthur and Stevens 2004), mountain big sagebrush strongly influences its community. The long taproots raise water from deep in the soil at night and may also transport new precipitation to deeper soils where it is less likely to evaporate (Richards and Caldwell 1987, Caldwell et al. 1998). This process may increase water availability for the sagebrush and may also positively affect nearby plants. A study using $\mathrm{D}_{2} \mathrm{O}$ applied to deep roots of mountain big sagebrush observed movement of labeled water into nearby grasses, indicating that hydraulic redistribution can increase water availability for nearby plants (Caldwell and Richards 1989).
However, another study showed that removal of big sagebrush had no effect on surface soil moisture but increased soil moisture in deeper horizons (Inouye 2006). Big sagebrush also creates a patchy distribution of nutrients; and carbon and nitrogen, organic carbon, and organic phosphorus occur at higher levels under big sagebrush canopies than between them (Charley and West 1975, Inouye 2006).

Climate models indicate that temperatures in the western United States will rise 0.8-1.7 ${ }^{\circ} \mathrm{C}$ by the mid-21st century (Barnett et al. 2005). Effects of climate change on precipitation in the Rocky Mountains are challenging to model due to complex topography. The NCAR-DOE Parallel Climate Model predicts little or no change in precipitation (Barnett et al. 2005), while the Hadley and Canadian General Circulation Models predict a generally drier climate with wetter winters and drier summers (Smith et al. 2001). All models, however, project decreased snow cover throughout the region (Smith et al. 2001, Cayan et al. 2001, Barnett et al. 2005, IPCC 2007). These

aSome studies cited in this paper occurred before differentiation of subspecies and so refer only to big sagebrush.

${ }^{1}$ Department of Biology, Colorado College, Colorado Springs, CO 80903.

${ }^{2}$ Present address: 2925 Legation St., NW, Washington, DC 20015

${ }^{3}$ Department of Ecology and Evolutionary Biology, University of Arizona, Tucson, AZ 85721.

${ }^{4}$ Corresponding author. E-mail: clamanna@email.arizona.edu 
decreases in snow cover and increases in temperatures have already been seen in the Northern Hemisphere, with indications that decreasing snow cover and corresponding changes in radiative balance may create a positive feedback, causing greater increases in spring temperatures (Groisman et al. 1994).

Most studies examining responses of sagebrush annual growth rings to precipitation have seen a positive correlation (Ferguson and Humphrey 1959, Ferguson 1964, Fowler and Helvey 1974). However, with a large part of precipitation in the Rocky Mountains falling as snow, total precipitation is only part of the picture. Responses of mountain big sagebrush to the extremes of snow depth are mixed. In a snow-fence experiment in southern Wyoming, increased snow depth and prolonged periods of soil saturation in the spring led to a high mortality of mountain big sagebrush (Sturges 1989). However, decreased winter snow depth can also be detrimental to sagebrush, as was seen during the 1967-1977 winter when sporadic warm days and dry, frozen soils caused widespread damage to mountain big sagebrush (Hanson et al. 1982, Nelson and Tiernan 1983). Moderate decreases in snow cover as predicted with climate change may have less direct effects through decreased soil moisture and increased growing season. A montane meadow warming experiment at $2920 \mathrm{~m}$ elevation found a negative correlation between average growth rate and later snowmelt dates (Perfors et al. 2003).

Although models predict substantial temperature increases in the Rocky Mountains, few studies have looked at effects of temperature on sagebrush. DePuit and Caldwell (1973) showed decreased photosynthesis with higher temperatures because of increased water stress. Yet as temperatures increased through the summer, sagebrush showed maximal efficiency at higher temperatures. In the montane meadow warming experiment, an increase in the biomass of sagebrush was observed on warmed plots, although this increase is more likely due to earlier snowmelt than to the direct effects of increased temperature (Harte and Shaw 1995, Loik et al. 2000). Overall, the potential effects of predicted increases in temperature on sagebrush are unclear.

This paper examines the simultaneous roles of temperature, precipitation, and snow depth in determining annual ring growth of big mountain sagebrush. We predicted that growth would be negatively related to summer temperature and positively related to precipitation and snow depth.

We collected mountain big sagebrush at a site just south of Almont within the Gunnison Basin, Colorado $\left(38.655^{\circ} \mathrm{N}, 106.861^{\circ} \mathrm{W}, 2460\right.$ $\mathrm{m})$. The study site is located about $200 \mathrm{~m}$ from the East River on a slight, southeast slope; it receives moderate cattle grazing. Mountain big sagebrush $30-70 \mathrm{~cm}$ in height dominates the area with forbs and grasses underneath and between the shrubs and with scattered Juniperus scopulorum.

We sampled 14 variously aged plants (range $2-59$ years) and a range of growth habits. Some plants had rings too deteriorated to measure, and only 5 plants contained long and clearenough chronologies to be used for cross-dating.

In the lab we cut cross sections at the thickest and most intact portion of the main stem and sanded each to allow individual growth rings to be seen clearly. We scanned each section at high resolution, including a ruler to obtain absolute measurements. Using the image processing program Image $\mathrm{J}(\mathrm{NIH}$ 2007), we placed points marking ring boundaries to measure the perpendicular width of each ring. Euclidian distance was used to calculate ring widths.

Annual growth rings of big sagebrush are diffuse, porous, and easily identifiable due to an interxylary cork layer added between new growth and growth from the previous year (Ward 1953). In stressful years, partial death of the cambium can occur, leading to localized growth in areas with still-living cambium. This irregular stem growth creates the characteristic lobed stems of sagebrush. Number of lobes varies from 1 to 10 . False rings occur in years with 2 surges of growth and are frequent at lower elevations but have not been encountered at higher elevations. Occasionally, rings are absent from some lobes of a plant in stressful years, but occurrence of missing rings around the entire circumference are rare (Ferguson 1964, Perryman and Olson 2000).

For each cross section we measured 2 to 3 lobes and cross-dated them by comparing graphical representations of ring widths. Within the 14 lobes we examined, only 3 had rings absent within lobes, and there were no rings missing in all lobes of a plant. Additionally, 4 lobes did not show rings in the most recent 
years and were adjusted accordingly. After lobes within a plant showed a strong correlation, we averaged rings of the same year and then standardized across all years within each plant $\left(\frac{x-\bar{x}}{s}\right.$, where $x$ is the mean ring width across all lobes for 1 year; $\bar{x}$ is the mean of these averaged widths across all years for that plant, and $s$ is the standard deviation of the $x$ values). We repeated the cross-dating among the 5 plants with usable cross sections to identify missing rings. Once we had a strong relationship in ring-width variation across the plants, we averaged and standardized the standardized ring widths for each year. This average lessens noise from individual plants and strengthens the climate signal (Fritts 1971).

Correlations between climatic variables and mean ring widths were calculated using various temporal windows for both temperature and precipitation. Temperature during the water year (November-October) was shown to be a good predictor of ring widths in pinyon pines (Kempes et al. 2008). However, we also wanted to gain a greater understanding of the role of seasonal climate, so we calculated correlations for mean temperatures in summer (May-October), spring (March-May), and winter (October-March). For precipitation, a study by Ferguson and Humphrey (1959) suggested a greater impact of precipitation in early summer (May-July) compared to late summer (July-October), so we calculated correlations for those time periods as well as for the 2 periods combined (May-October), the water year, the winter (October-March), and the spring (March-May). Since snowmelt may play an important role in recharging deep soil moisture and may therefore be important to sagebrush growth, we also correlated standardized ring widths with maximum snow depth at any time during the latter part of winter (January-April) and with maximum April snow depth, just before spring melt.

We used multiple regressions with standardized variables to determine the relative importance of temperature, precipitation, and snow depth in controlling ring widths. For each of the 3 climatic variables, we chose the one temporal window with the highest correlation with ring widths.

All weather data were obtained from a weather station in Crested Butte, Colorado $\left(38.9^{\circ} \mathrm{N} 107^{\circ} \mathrm{W}, 2699 \mathrm{~m}\right), 25 \mathrm{~km}$ north of the study area (NCDC 2009). All calculations were done in Microsoft Excel, except the multiple regressions, which were done with Minitab version 15.

The 5 plants we were able to cross-date yielded strong correlations among lobes within plants (Pearson $r=0.72$ to 0.91 ). Cross-dating between pairs of plants was also successful $(r$ $=0.41$ to 0.76 for various pairs, $P<0.01$ for all). As not all of the sagebrush sequences were of equal length, we examined the time span of the shortest cross section-39 years from 1969 to 2007 .

All temperature windows correlated significantly and negatively with ring widths (Fig. 1; $r=-0.42$ to $-0.62, P<0.01$ ), except winter temperature, which showed a nonsignificant correlation $(r=-0.17, P=0.321)$. The strongest correlation was for summer temperature $(r=-0.62)$. For precipitation, we observed strong positive correlations between ring widths and winter precipitation $(r=0.68$, $P<0.001)$, spring precipitation $(r=0.54, P<$ $0.001)$, and water year $(r=0.63, P<0.001)$. There was a weak correlation with early summer precipitation $(r=0.33, P=0.042)$ and none with late summer $(r=-0.08, P=0.654)$ or total summer precipitation $(r=0.17, P=$ 0.315). Snow depth showed strong positive correlations with ring widths (maximum snow depth in April, $r=0.71, P<0.001$; maximum winter snow depth, Fig. $2, r=0.74, P<0.001$ ).

Multiple regressions with relatively high $r^{2}$ values and regression coefficients similar in absolute value suggest that both summer temperature and either winter precipitation or maximum winter snow depth are important in controlling growth (Table 1). The fit using maximum snow depth (adjusted $r^{2}=0.60$ ) was somewhat better than the fit using winter precipitation (adjusted $r^{2}=0.49$ ).

Both the simple correlations and the multiple regressions indicate that growth of mountain big sagebrush is water limited. This conclusion is supported by strong positive correlations with various precipitation windows, except for late summer precipitation, which comes after major growth has ceased for the year (Ferguson and Humphrey 1959). The strong negative correlation with summer temperatures also supports this conclusion, as hot summer days increase water stress. The strong positive relationship with maximum winter snow depth suggests that the recharge of deep groundwater during late winter and spring 

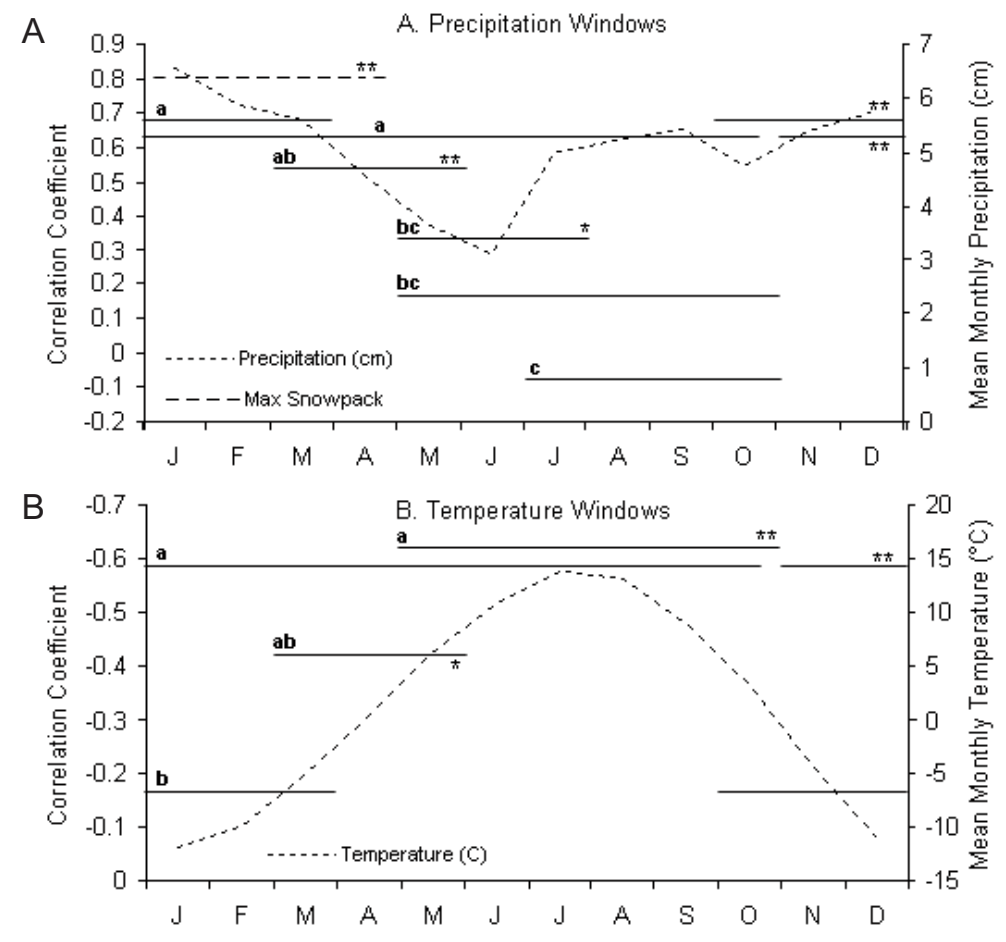

Fig. 1. Correlation coefficients ( $P<0.05$, $* * P<0.001)$ of standardized ring widths of mountain big sagebrush with several temporal windows: A, precipitation; B, temperature. Weather data were measured at Crested Butte, Colorado (NCDC 2009; mean monthly temperature and precipitation 1969-2007 with 1977-1979 missing for temperature; maximum snowpack data 1969-2007 with 1974, 1977, 1982, 1996, and 1998 missing). Different letters indicate correlations outside the $95 \%$ confidence intervals of correlation coefficients with other letters.

snowmelt is very important to growth of this species.

The increased summer temperatures predicted by climate models will likely decrease growth of mountain big sagebrush. Given the strong correlation between winter precipitation and maximum snow depth (this study: $0.88, P<$ 0.001 ), it is not possible with observational data to separate effects of late winter and early spring rains from the effect of maximum snow depth. If models that predict increased winter precipitation are correct, it might be possible that the resulting increase in sagebrush growth could partially offset effects of increasing temperatures. However, increased winter temperatures might also cause more precipitation to fall as rain rather than snow. More of this water might evaporate, and the recharge of deep soil profiles could decrease. This scenario would exacerbate decreases in growth caused by higher summer temperatures.

If mountain big sagebrush growth rates do decrease in the future, this decrease could reduce sagebrush populations at the lower elevational limit where water stress is greatest, and this reduction would impact other aspects of the community. Inouye (2006) showed that sagebrush removal increased soil moisture and perennial grass cover.

Effects on carbon balance and soil $\mathrm{C}$ are unclear and may vary with replacement species. Bechtold and Inouye (2007) found that removal of A. tridentata ssp. tridentata led to higher soil C after 6 years, presumably due to more litter input and fine roots of perennial grasses. Replacement of $A$. tridentata by the invasive annual grass Bromus tectorum had mixed effects on soil C (Bolton et al. 1993, Norton et al. 2004).

At sites not at the lower limit of the population, decreased annual growth may correspond with decreased sagebrush cover, which could have similar but less dramatic effects on the community.

However, these predictions assume little evolutionary response by the species. Subspecies of A. tridentata and also other species 

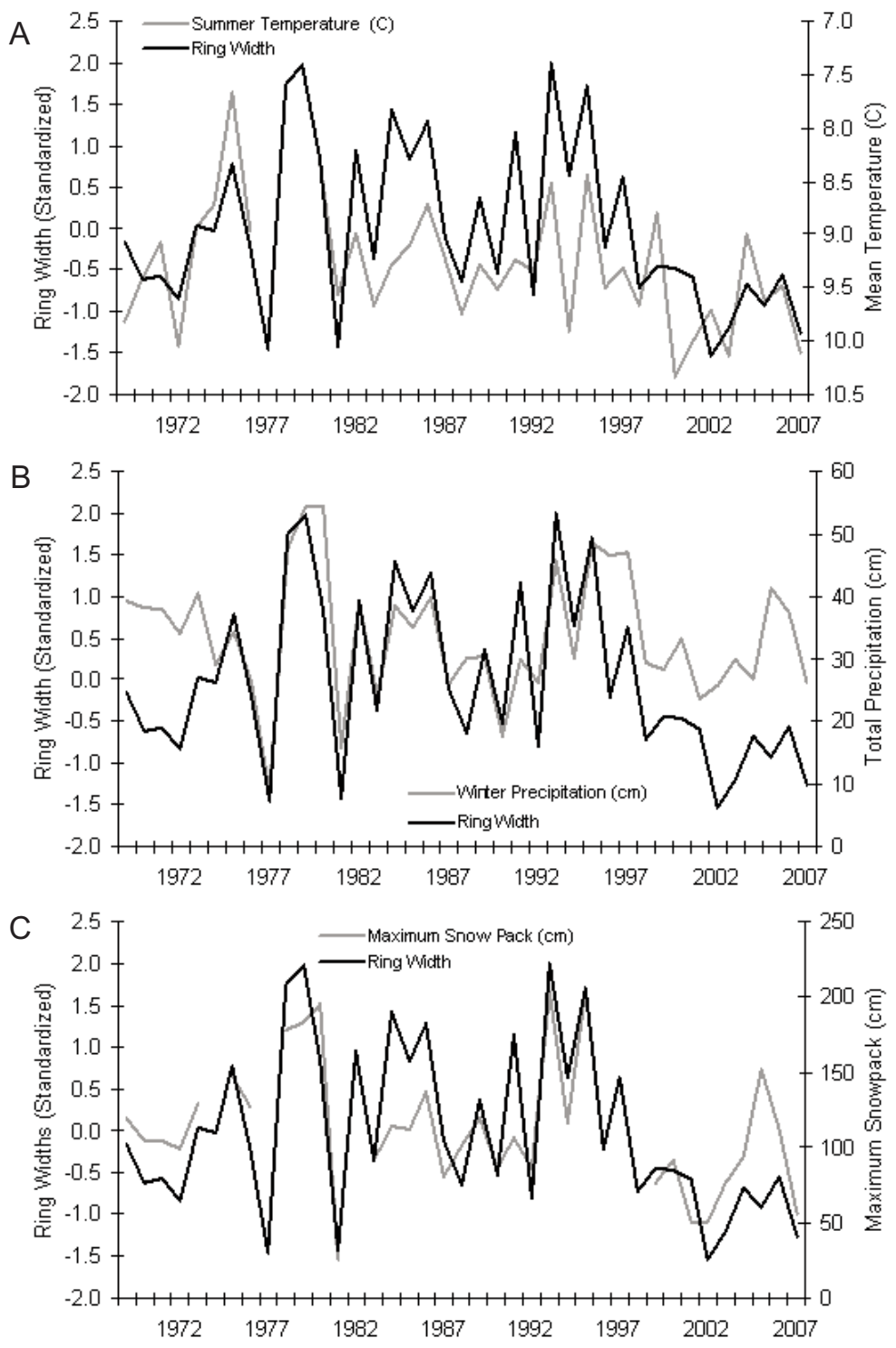

Fig. 2. Standardized mean ring widths of mountain big sagebrush compared to (A) summer temperature (May-October, note inverted axis); (B) winter precipitation (October-March); and (C) maximum snow depth (January-May; weather data from NCDC 2009).

within the subgenus Tridentatae have many points of contact and commonly hybridize. Hybrids show intermediate form and physiology, and they are better adapted to the intermediate zone than either of the parents (McArthur et al. 1998). Additionally, subspecies of A. tridentata, including ssp. vaseyana and its hybrid with A. $t$. ssp. tridentata, occur both as diploids and tetraploids even within populations. Polyploidy events provide reproductively isolated groups that can then undergo selection (McArthur and Sanderson 1999). The high occurrence of hybridization and polyploidy in A. tridentata and its related species might allow these taxa to respond relatively quickly to climate change compared to other species.

Changes in mountain big sagebrush growth rates and perhaps distribution and cover have the potential to greatly impact the large areas of sagebrush-dominated communities 
TABLE 1. Multiple regressions predicting ring widths as functions of summer temperature and either winter precipitation or maximum winter snowpack.

\begin{tabular}{lrr}
\hline & $\begin{array}{r}\text { Regression } \\
\text { coefficient }\end{array}$ & $P$ \\
\hline Temperature and precipitation & & \\
Adjusted $r^{2}=0.49$ & & \\
$\quad$ Summer temperature (May-Oct) & -0.42 & 0.001 \\
$\quad$ Winter precipitation (Oct-Mar) & 0.42 & 0.005 \\
Temperature and snow depth & & \\
Adjusted $r^{2}=0.60$ & & \\
$\quad$ Summer temperature (May-Oct) & -0.41 & 0.034 \\
Maximum snow depth (Jan-May) & 0.52 & 0.004 \\
\hline
\end{tabular}

throughout western North America. While some studies have modeled effects of climate change on sagebrush and predicted replacement by shrubs common to more arid regions (Hansen et al. 2001), not enough research has been done to understand the effects of changing climate on sagebrush.

We thank Robin Sleith for his encouragement and field assistance and also the Rocky Mountain Biological Laboratory (RMBL), especially John Harte and Ian Billick. BEP was supported by a National Science Foundation (NSF) REU institutional award to RMBL and a Venture Grant from Colorado College. CAL, $\mathrm{BEP}$, and BJE were partially supported from an NSF CAREER Award to BJE.

\section{Literature Cited}

Barnett, T.P., J.C. Adams, And D.P. Lettenmaier. 2005. Potential impacts of a warming climate on water availability in snow-dominated regions. Nature 438: 303-309.

Bechtold, H.A., AND R.S. INOuYe. 2007. Distribution of carbon and nitrogen in sagebrush steppe after six years of nitrogen addition and shrub removal. Journal of Arid Environments 71:122-132.

Bolton, H., Jr., J.L. Smith, And S.O. Link. 1993. Soil microbial biomass and activity of a disturbed and undisturbed shrub-steppe ecosystem. Soil Biology and Biochemistry 25:545-552.

Caldwell, M.M., T.E. Dawson, and J.H. Richards. 1998. Hydraulic lift: consequences of water efflux from the roots of plants. Oecologia 113:151-161.

Caldwell, M.M., AND J.H. Richards. 1989. Hydraulic lift: water efflux from upper roots improves effectiveness of water uptake by deep roots. Oecologia 79:1-5.

Cayan, D.R., S.A. Kammerdiener, M.D. Dettinger, J.M. Caprio, and D.H. Peterson. 2001. Changes in the onset of spring in the western United States. Bulletin of the American Meteorological Society 82: 399-415.

Charley, J.L., and N.E. West. 1975. Plant-induced soil chemical patterns in some shrub-dominated semi-desert ecosystems of Utah. Journal of Ecology 63:945-963.

DePuit, E.J., and M.M. Caldwell. 1973. Seasonal pattern of net photosynthesis of Artemisia tridentata. American Journal of Botany 60:426-435.

Ferguson, C.W. 1964. Annual rings in big sagebrush. Papers of the Laboratory of Tree-Ring Research, No. 1. University of Arizona Press, Tucson.

Ferguson, C.W., AND R.R. Humphrey. 1959. Growth rings of sagebrush reveal rainfall records. Progressive Agriculture of Arizona 11:3.

Fowler, W.B., AND J.D. Helvey. 1974. Reading the weather in sagebrush. Pacific Search 9(3):10.

FritTs, H.C. 1971. Dendroclimatology and dendroecology. Quaternary Research 1:419-449.

Groisman, P.Y., T.R. KarL, and R.W. Knight. 1994. Changes of snow cover, temperature, and radiative heat balance over the Northern Hemisphere. Journal of Climate 7:1633-1656.

Hansen, A.J., R.R. Neilson, V.H. Dale, C.H. Flather, L.R. Iverson, D.J. Currie, A. Shafer, R. Cook, and P.J. BaRTLEIN. 2001. Global change in forests: responses of species, communities, and biomes. BioScience 51:765-779.

Hanson, C.L., C.W. Johnson, and J.R. Wight. 1982. Foliage mortality of mountain big sagebrush [Artemisia tridentata subsp. vaseyana] in southwestern Idaho during the winter of 1976-1977. Journal of Range Management 35:142-145.

Harte, J., AND R. Shaw. 1995. Shifting dominance within a montane vegetation community: results of a climate-warming experiment. Science 267:876-880.

INOUYE, R.S. 2006. Effects of shrub removal and nitrogen addition on soil moisture in sagebrush steppe. Journal of Arid Environments 65:604-618.

[IPCC] Intergovernmental Panel on Climate Change. 2007. Summary for policymakers. In: S. Solomon, D. Qin, M. Manning, Z. Chen, M. Marquis, K.B. Averyt, M. Tignor, and H.L. Miller, editors, Climate change 2007: the physical science basis. Contribution of Working Group I to the Fourth Assessment Report of the Intergovernmental Panel on Climate Change. Cambridge University Press, New York.

Kempes, C.P., O.B. Myers, D.D. Breshears, and J.J. EBERSOLE. 2008. Comparing response of Pinus edulis tree-ring growth to five alternate moisture indices using historic meteorological data. Journal of Arid Environments 72:350-357.

Loik, M.E., S.R. Redar, and J. Harte. 2000. Photosynthetic responses to a climate-warming manipulation for contrasting meadow species in the Rocky Mountains, Colorado, USA. Functional Ecology 14:166-175.

Mcarthur, E.D., D.C. Freeman, J.H. Graham, H. Wang, S.C. Sanderson, T.A. Monaco, and B.N. SMITH. 1998. Narrow hybrid zone between two subspecies of big sagebrush (Artemisia tridentata: Asteraceae). VI. Respiration and water potential. Canadian Journal of Botany 76:567-574.

McArthur, E.D., AND J.E. OTT. 1996. Potential natural vegetation of the 17 conterminous Western United States. Pages 16-28 in J.R. Barrow, E.D. McArthur, R.E. Sosebee, and R.J. Taush, compilers, Proceedings: shrubland ecosystem dynamics in a changing environment. General Technical Report INT-GTR338, USDA Forest Service, Ogden, UT.

McArthur, E.D., and S.C. Sanderson. 1999. Cytogeography and chromosome evolution of subgenus 
Tridentatae of Artemisia (Asteraceae). American Journal of Botany 86:1754-1775.

McArthur, E.D., and R. Stevens. 2004. Composite shrubs. Pages 493-537 in S.B. Monsen, R. Stevens, and N.L. Shaw, compilers, Restoring western ranges and wildlands. General Technical Report RMRSGTR-136-vol. 2.

[NCDC] National Climatic Data Center. 2009. Digital files. Asheville, NC; [accessed 7 January 2009]. Available from: http://www.ncdc.noaa.gov/oa/mpp /digitalfiles.html.

[NIH] National Institutes of Health. 2007. Image J: image processing and analysis in JAVA. Bethesda, MD; [accessed 7 January 2009]. Available from: http://rsb.info.nih.gov/ij/.

Nelson, D.L., and C.F. Tiernan. 1983. Winter injury of sagebrush and other wildland shrubs in the western United States. Research Paper INT-314, USDA Forest Service, Intermountain Forest and Range Experiment Station, Ogden, UT.

Norton, J.B., T.A. Monaco, J.M. Norton, D.A. Johnson, AND T.A. JONEs. 2004. Soil morphology and organic matter dynamics under cheatgrass and sagebrushsteppe plant communities. Journal of Arid Environments 57:445-466.

Perfors, T., J. Harte, and S.E. Alter. 2003. Enhanced growth of sagebrush (Artemisia tridentata) in response to manipulated ecosystem warming. Global Change Biology 9:736-742.

Perryman, B.L., and R.A. Olson. 2000. Age-stem diameter relationships of big sagebrush and their management implications. Journal of Range Management 53:342-346.
Richards, J.H., and M.M. Caldwell. 1987. Hydraulic lift: substantial nocturnal water transport between soil layers by Artemisia tridentata roots. Oecologia 73:486-489.

Schultz, L.M. 2006. Artemisia. Pages 503-534 in Flora of North America Editorial Committee, editors, Flora of North America North of Mexico. Volume 19. Oxford University Press, New York and Oxford.

Smith, J.B., R. Richels, and B. Milleer. 2001. Potential consequences of climate variability and change for the western United States. Pages 219-245 in National Assessment Synthesis Team, compilers, Climate change impacts on the United States: the potential consequences of climate variability and change. Cambridge University Press, Cambridge, United Kingdom.

StURGES, D.L. 1989. Response of mountain big sagebrush to induced snow accumulation. Journal of Applied Ecology 26:1035-1041.

Ward, G.H. 1953. Artemisia, section Seriphidium, in North America: a cytotaxonomic study. Contributions from the Dudley Herbarium 4:155-205.

West, N.E., R.J. Tausch, K.H. Rea, and P.T. Tueller. 1978. Taxonomic determination, distribution, and ecological indicator values of sagebrush within pinyon-juniper woodlands of the Great Basin. Journal of Range Management 31:87-92.

Received 13 February 2009 Accepted 6 July 2009 